$\underline{\text { Relational and Identity Perspectives on Healthy versus Unhealthy Pursuit of Callings }}$

By: M. Teresa Cardador and Brianna B. Caza

Cardador, T. \& Caza, B.B. (2012). Relational and Identity Perspectives on Healthy versus

Unhealthy Pursuit of Callings. Journal of Career Assessment, 20(3), 338-353.

https://doi.org/10.1177/1069072711436162

$* * *$ (C) 2012 The Authors. Reprinted with permission. No further reproduction is authorized without written permission from SAGE. This version of the document is not the version of record. Restricted to non-commercial and no derivative uses. $* * *$

\begin{abstract}
:
Despite growing research on the perceived desirability and positivity of callings, there is intriguing evidence that while many experience personal benefits associated with viewing their work as a calling, others may experience detrimental effects. This discrepancy highlights the need to better understand when pursuing a calling might be positive or negative for individuals and to identify potential conditions under which such positive or negative outcomes may occur. In this article, the authors take a relational perspective on what they refer to as "healthy" versus "unhealthy" pursuit of callings, highlighting the conditions under which callings might be beneficial versus problematic for one's personal relationships, and relationships with coworkers and one's employing organization. Furthermore, our theoretical framework incorporates an identity perspective emphasizing work-identity flexibility as a critical factor that explains when and why pursuing one's callings might be associated with positive and enriching relationships for some, but negative and depleting relationships for others.
\end{abstract}

Keywords: callings | calling orientation | unhealthy pursuit of calling | work-identity flexibility | relationships

\title{
Article:
}

As a result of the growing centrality of work in people's lives (Hall \& Chandler, 2005), and the greater opportunity to seek fulfillment of personal goals through work (Judge \& Bretz, 1992), people are increasingly looking to work as a key source of meaning and self-definition (Colby, Sippola \& Phelps, 2001; Shamir, 1991). Many workers want their work to be more than merely a source of income (a job) or an avenue for advancement and accomplishment (a career). Instead, individuals are looking for their work to provide intrinsic meaning and an opportunity to make a difference. In other words, individuals are increasingly looking to their work to provide a sense of calling (Dik \& Duffy, 2009; Duffy \& Sedlacek, 2007; Wrzesniewski, 2011; Wrzesniewski, Dekas, \& Rosso, 2009). Workers expect that once they find their calling, they will be rewarded with personal meaning and fulfillment through work (Novak, 1996). Popular media reinforces this notion with an ever-growing number of books, podcasts, television programs, and other resources devoted to helping people discover their true calling. 
Consistent with this growing emphasis on identifying and pursuing one's calling, scholars have devoted more attention to the topic of callings in recent years (e.g., Bunderson \& Thompson, 2009; Cardador, Dane \& Pratt, 2011; Dik \& Duffy, 2009; Duffy, Dik \& Steger, 2011; Duffy \& Sedlacek, 2007; Elangovan, Pinder, \& McLean, 2010; Wrzesniewski, 2010), noting the personal psychological payoffs, as well as the ways in which organizations might benefit. Yet, despite their perceived desirability and positivity, there is intriguing evidence that callings are not always beneficial, and in fact, may actually be detrimental in some ways. For example, researchers have noted that those with callings can develop "career tunnel vision," characterized by a resistance to feedback from others and a lack of adaptability in their work (Dobrow, 2006). Others have observed that the need to devote everything to one's calling may involve personal sacrifice (Serow, 1994) and come at the expense of other aspects of life (Levoy, 1997). Another study found that a deep sense of calling was associated with higher levels of burnout due to high expectations for one's own and others' level of performance (Vinje \& Mittelmark, 2007). Other researchers have demonstrated that individuals' relationship with their employing organization can also be impacted by their orientation toward work as a calling. For instance, Bunderson and Thompson (2009) found that callings could be a "double-edged sword," providing zookeepers with a sense of passion, but putting them at risk not only for personal sacrifice but even for exploitation by their work organizations. Other work has suggested that having a calling can lead to decreased identification with one's employing organization because the work itself, and not the place in which one does the work, is likely to be of ultimate importance for those with callings (Pratt \& Ashforth, 2003).

Many of these potentially detrimental outcomes associated with callings may become more salient the longer one is in a career, such that while entering a particular profession or occupation with a calling might have positive benefits, there seems to be evidence from professions long associated with callings that sustaining the positive benefits of having a calling throughout one's career may be more challenging. For example, two common professions associated with callings, nursing and teaching, have demonstrated that the positive effects of having a calling start to wane after a period of time. Specifically, nurses experience elevated rates of burnout (Sherman, 2004), and teachers leave the classroom in high rates during the first 5 years of service (Hartnett \& Kline, 2005). This is what some observers of these professions have begun to term the "fall from the call" (Hartnett \& Kline, 2005), and is in line with early research on work burnout suggesting that individuals can only burnout if they were once "on fire" (Pines, Aronson, \& Kafry, 1981). This suggests that the variance in the effect of calling on individuals' subjective well-being may become more salient over time.

Taken together, the extant literature on callings suggests that while many experience personal benefits associated with viewing their work as a calling, others may experience detrimental outcomes in pursuit of their ideal work. This discrepancy highlights the need to better understand when pursuing a calling might be positive or negative for individuals' well-being, and to identify potential conditions under which such positive or negative experiences may occur. The purpose of this article, therefore, is to outline a theoretical perspective focused on these issues. In doing so, we challenge the prevailing notion that it is always good to pursue one's calling. In this article, we combine relational and identity perspectives to offer insights into when and why pursuing one's calling may be beneficial or detrimental to the individual's subjective well-being. 
Taking a cue from other researchers, we define subjective well-being broadly as one's cognitive and affective evaluation of their life (Diener, 2000).

A relational perspective is particularly relevant to a discussion of callings, given the importance of relationships and interpersonal sense making for understanding the meaningfulness of one's work (Wrzesniewski, Dutton, \& Debebe, 2003), and given that a calling orientation is theorized to shape how we think about and behave toward others at work (Wrzesniewski, 2011). Specifically, we present evidence that people's orientation toward their work as a calling could impact relationships in two divergent ways. First, it might strengthen interpersonal relationships both inside and outside the workplace. When individuals have a calling, they may be likely to inspire and connect with others, and behave more positively in their relationships. In other words, one's calling could be enriching to their relationships. We adopt the term "unhealthy pursuit of one's calling" to refer to this scenario. However, one's pursuit of their work as a calling might also have a very different effect, alienating others in the process of pursuing one's calling. We refer to this as an unhealthy pursuit of one's calling. We outline the evidence in support of both possibilities. As much of the research on callings has focused on workers' views of the work itself (Dik \& Duffy, 2009; Duffy \& Sedlacek, 2007; Hall \& Chandler, 2005; Wrzesniewski, 2003), enhancing an understand of how callings might affect one's relationships with others and their organization offers an expanded view of people's experience with callings.

We combine this relational perspective with an identity perspective on the pursuit of one's calling. We propose that work-identity flexibility is a factor that explains when and why pursuing one's calling might be associated with positive and enriching relationships for some, but negative and depleting relationships for others. We support our arguments by drawing on the evidence that many of the effects of callings work through identity pathways (Pratt \& Ashforth, 2003). In doing so, we suggest that a calling is an attitude that refers to one's ideal relationship with work. Once individuals encounter the reality of their profession, they may need to make adjustments to this ideal (Pratt, Rockmann \& Kaufmann, 2006). Yet, as research has shown, even adjustments to one's identity can be difficult to make, especially the more individuals become committed to, or "entrenched" in, a particular identity (Weick, 1993). We suggest that the flexibility of one's work identity will shape how individuals pursuing callings respond to their personal and work-related relationships, and thus whether pursuing the calling is healthy or unhealthy with respect to personal well-being.

In order to explain why some individuals have healthy pursuits of their callings, while others experience unhealthy pursuits of their calling, we begin with a brief review of the calling literature, highlighting the relevance of relational and identity perspectives for understanding workers' experiences of callings. Second, we present a relational perspective on callings and well-being. We relate this perspective to a healthy pursuit of one's calling and to an unhealthy pursuit of one's calling, describing situations in which a calling is positive and enriching versus negative and depleting to workers' relationships. Third, we introduce the concept of workidentity flexibility as an important mechanism that shapes when pursuing a calling can be beneficial or detrimental to one's relationships.

\section{Calling Orientations}


Although the notion that all areas of work can be pursued as a calling dates at least to the 16th century, the interest in callings by social scientists is a relatively recent phenomenon. In the mid1980s, Bellah, Madsen, Sullivan, Swidler, and Tipton (1985) used the term calling in reference to one of the three orientations that individuals can hold toward work (the other two orientations are a job and a career). They described those with callings as having work that they perceive to be personally fulfilling and socially valuable. A decade later, researchers operationalized Bellah's notion of work orientation through an empirical examination of employees from multiple occupations (Wrzesniewski, McCauley, Rozin, \& Schwartz, 1997). Work orientations are considered to (a) capture one's belief about the role of work in life, (b) inform people's basic goals for working, and (c) influence work-related feelings and behavior (Wrzesniewski, 2003, 2010).

Since these early conceptualizations, scholars have further expanded the notion of callings. Some scholars associate callings with a "transcendent summons," noting that callings may stem from God or some external source, such as the needs of society (Dik \& Duffy, 2009). Others argue that a calling stems from within the individual and is derived through introspection, as well as an understanding of one's interests and talents (Hall \& Chandler, 2005; Hunter, Dik \& Banning, 2010). Still others combine internal and external sources of calling, suggesting that callings are marked by personal passion, a sense of duty, sacrifice, and transcendent meaning (Bunderson \& Thompson, 2009). While no consensus definition of calling has been achieved (Hirschi, 2011), contemporary views of calling share in common the idea that a calling entails a sense of purpose and meaning in work. Drawing on existing research, we define a calling orientation as a view toward work in which one expects the work to be intrinsically meaningful and sees the work as making a difference in some way (Bunderson \& Thompson, 2009; Duffy et al., 2011; Wrzesniewski et al., 1997).

Callings have been closely linked to personal identity. Scholars have noted that callings are associated with strong identification with one's work and occupation (Bunderson \& Thompson, 2009; Dobrow, 2004), and that one's view of work as a calling is closely connected to one's sense of self (Pratt \& Ashforth, 2003). Those with callings view work as an integral part of themselves, as well as their life outside of work (Wrzesniewski et. al., 1997). Work is considered to be central and valued and is often viewed as one of the most important aspects of life (Dobrow 2004; Hirschi, 2011). One reason for the strong work identity associated with callings is that this view of work is thought to be closely connected to one's personal values and to derive from considerable personal introspection, reflection, and discernment (Hall \& Chandler, 2005).

This condensed review highlights two important features of extant research on callings that have relevance for the current research. First, much of the research on callings has connected the experience of callings with one's view of the work itself, rather than with the relationships associated with work. There is a paucity of research linking callings to one's experience of personal and work relationships, and perhaps a needlessly narrow view of people's experience of callings. Taking a relational perspective, we argue that the impact of pursuing one's calling should be clearly seen in one's relationships (Wrzesniewski, 2010).

A second feature highlighted by our review of the calling literature is the connection between callings and one's work identity; scholars have noted that callings are generally associated with a 
strong work identity, such that the meaning of one's work is closely connected to one's sense of "who I am" (Dobrow, 2004; Hirschi, 2011; Pratt \& Ashforth, 2003). However, researchers have yet to uncover the specific ways in which work identity may interface with one's calling to shape one's experience of work. We combine these features to present relational and identity perspectives on healthy versus unhealthy pursuit of callings.

\section{A Relational Perspective on Callings and Well-Being}

Human beings have a strong desire to form lasting and positive relationships with others, and such relationships have a profound influence on personal well-being (cf. Baumeister \& Leary, 1995; Dutton \& Heaphy, 2003; Gersick, Dutton, \& Bartunek, 2000; Ryan \& Deci, 2000). Positive relationships are considered a central source of life satisfaction, enrichment, and development for individuals (cf. Ragins \& Dutton, 2007; Reis \& Gable, 2003). Given the tight connection between positive relationships and a host of well-being indicators (Roberts, 2007), as well as evidence that interpersonal conflict or lack of social support have detrimental consequences for personal well-being in both the short and the long run (De Dreu, Van Dierendonck, \& De Best-Waldhober, 2002), organizational researchers are more interested than ever in understanding the important interaction between one's work and one's personal relationships (Wrzesniewski et al., 2003).

What distinguishes positive and enriching relationships from those that are negative or depleting? While positive relationships have been variously defined, many definitions share the idea that these types of relationships are experienced as mutually rewarding and create possibilities for personal development and growth (Dutton \& Heaphy, 2003; Kahn, 2007). Deleterious or negative relationships, in contrast, are unrewarding to the individuals involved and inhibit personal development and expression (Ragins \& Dutton, 2007). Such relationships are often characterized by stress, conflict, and a lack of support.

A relational perspective on personal well-being places importance on positive relationships as sources of well-being, and negative relationships as undermining to one's psychological health (Baumeister \& Leary, 1995; Kahn, 2007). Applying a relational perspective to callings, we suggest that the impact of one's calling should be seen not only in one's work but also in the quality of one's relationships with others. This should be the case for a number of reasons. First, as noted, one's view of work as a calling is likely to shape how one thinks and behaves toward others (Wrzesniewski, 2010). Second, work relationships are critical in serving organizational roles and completing most work tasks (Kahn, 2007). As the fulfillment of work goals is of particular importance to those with callings, relationships with others should be considered critical. Third, relationships provide a sense of being valued, as well as feedback about one's contribution (Wrzesniewski et al., 2003), both of which should be considered important to those who attach high levels of meaning to work. As Wrzesniewski, Dutton, and Debebe (2003) note, "Because the meaning of work is largely constituted at work, with others, it becomes a living social account that employees make of their experience at work" (p. 97). Accordingly, the meaning of one's work - specifically of work as a calling — should shape interactions and relationships with others both inside and outside of work. One's pursuit of work as a calling should have implications for the nature and quality of his or her social ties. We suggest that the pursuit of one's calling could have either positive and enriching or negative and depleting effects 
on one's personal and work relationships. We develop each of these possibilities in the following two sections below.

When pursuing a calling is unhealthy

As noted previously, those with strong callings show high levels of investment in, and expectations for, their work, fellow workers, and employing organization (Bunderson \& Thompson, 2009). Some have even suggested that those with callings are constantly "hungry" and never content with work, such that they may have a constant dissatisfaction at what is not being achieved (Hirschi, 2011). This notion is supported by evidence that when individuals have high investment in a particular role, they are likely to have high standards for that role and those associated with it (Ashforth, 2001). In some instances, these strong expectations can have negative effects on work-related relationships. For example, research shows that when individuals have exceedingly high work standards and expectations, they find it difficult to trust colleagues to perform up to their standard (Porter, 1996). As a result, they show a tendency toward lack of trust of colleagues and nondelegation (Spence \& Robbins, 1992). Moreover, high expectations for self and others can create stress, undermine worker cohesion (Johnstone \& Johnson, 2005), create hostile work relationships, and spur ineffective team relationships (Scott, Moore, \& Miceli, 1997). As a result, high expectations can negatively affect one's relationships with coworkers (Sirgy \& Wu, 2009). The passion and inner drive to do the work comes at the expense of openness toward others associated with the work role (Scott et al., 1997). Under these conditions, workers have difficulty adjusting to situational and relational demands and receiving feedback from others (Dobrow, 2006), and may have trouble experiencing pleasure in, and deriving support from, work relationships (Sirgy \& Wu, 2009). This is likely to result in disengagement (Kahn, 1998) and a reduced sense of positively influencing others through work (Gini, 1998).

Furthermore, there is evidence that pursuing one's calling can interfere with one's personal relationships ( $\mathrm{Ng}$, Sorensen, \& Feldman, 2007). Theories of work-life balance have provided evidence that investing heavily in one work role can make it difficult to fulfill the obligations of other roles and relationships (Greenhaus \& Buetell, 1985), suggesting that in some cases, one's work role can have a depleting effect (Rothbard, 2001). Depletion theories explain the way in which an individual's investment in the work role can strain nonwork roles and relationships by draining energy, resources, and time (Eckenrode \& Gore, 1990). When investment in the work role takes precedent over other roles and relationships, it can strain personal relationships outside of work (Carlson, Witt, Zivnuska, Kacmar, \& Grzywacz, 2008), reduce work-life balance (Bakker, Demerouti, \& Burke, 2009), and decrease one's satisfaction with social relationships (Piotrowski \& Vodanovich, 2006). For example, Bunderson and Thompson's (2009) study of zookeepers showed that individuals with a greater sense of calling were more willing to make personal sacrifices, such as time and personal well-being, for work. Similarly, Serow's (1994) study of teachers showed that those with callings tended to work more and invest more of themselves at work. Individuals who make significant sacrifices for work may allow themselves fewer opportunities to develop and nurture their personal relationships (Ganster \& Schaubroeck, 1991). As a result, these relationships may languish when individuals are in pursuit of their calling. 
In some cases, having a calling may also strain the relationship with one's employing organization. Pratt and Ashforth (2003) have theorized that those with callings may prefer to focus on the work, thereby disentangling themselves from organizational relationships.

Bunderson and Thompson (2009) have further suggested that a sense of calling can be associated with "heightened expectations about management's moral duty related to the work, leading to an employment relationship characterized by vigilance and suspicion" (p. 52). This evidence suggests that those with callings may view their organizations as inconsequential at best, and with distrust at worst. Both should contribute to an overall wakening of relationships with organizations for some people with strong callings.

To summarize, research has shown that in some circumstances, callings may strain personal and work-related relationships, isolate workers from others and make work less enjoyable, all of which should result in diminished worker well-being. For those for whom pursuit of callings is unhealthy, personal relationships with others and the organization are seen as barriers to the realization of one's calling due to differences in expectations, investment, and ideological commitments to work.

When pursuing a calling is healthy

Not everyone who pursues their calling will develop negative personal and work-related relationships as a result. In fact, there is evidence that sometimes individuals enjoy increased positivity and quality in their relationships. From a relational perspective, pursuing a calling is likely to be healthy when the person's investment in the work role is associated with supportive and mutually rewarding personal and work relationships. In other words, when pursuing a calling results in the development of positive and enriching relationships with coworkers, the organization or individuals in one's personal life. These types of relationships are important to one's well-being because they provide the resources and support needed to buffer or recover from negative or difficult situations and events (Gersick et al., 2000).

Individuals engaged in healthy pursuit of callings should develop more positive relationships with others at work. These individuals are still likely to have high levels of investment in work and high standards for themselves and those around them (Bunderson \& Thompson, 2009); however, those engaged in healthy pursuit of their calling should be better able to effectively work with others toward advancement of work goals. Much like transformational leaders, those engaged in healthy pursuit of a calling should also be likely to employ a visionary approach inspiring others to develop and grow in their work (Seltzer, Numerof, \& Bass, 1989). Through their attitudes and behaviors, these individuals may generate among their coworkers greater awareness and commitment to the purpose and mission of their group. This should result in increased respect and trust between those with callings and their coworkers (Pratt \& Dirks, 2007). In a similar fashion, those engaged in healthy pursuit of their callings may feel more positive about their work and lives (Wrzesniewski et al., 1997). As a result of their positive affective state, they should show more cooperative and prosocial behavior toward others (Isen $\&$ Baron, 1991), thereby developing greater connection and mutuality among coworkers. For these reasons, we suggest that those engaged in healthy pursuit of their callings should have more positive work relationships. 
These people should also be more likely to experience balance in their nonwork relationships. This is consistent with enrichment arguments associated with work-life balance, which suggest that in some instances, investment in one's work role can enhance other roles and personal relationships (Rothbard, 2001). For those engaged in a healthy pursuit of their calling, the calling may lead to energy expansion, reduced interrole tension and increased positive affect directed at nonwork relationships (Oates, Hall, \& Anderson, 2005). Individuals have the desire and the energy to invest in nonwork relationships and may even experience dual callings-callings in work and nonwork domains (Sellers, Batts, Thomas, \& Ostman, 2005). When those with callings invest in nonwork relationships and roles, they may experience a sense of balance, where fulfillment of one's calling has a positive effect on other parts of their lives (Sirgy \& Wu, 2009).

Pursuit of one's calling should also be healthy for one's well-being when workers are able to maintain positive and mutually rewarding relationships with their organization. We suggest that individuals in healthy pursuit of callings should be more likely to look to their organization, not with suspicion, but rather as an important means of achieving their desired outcome, realization of their calling (Cardador et al., 2011). Under this scenario, organizations will be seen by those with callings as providing key resources (e.g., training, coworkers, clients, and patients) to facilitate achievement of valued work goals (Kennedy, Loughry, Klammer, \& Beyerlein, 2009). Employees will not simply endure organizational shortcomings; rather, they will actively invest in their organizations to ensure that involvement in the organization serves a meaningful purpose (Cardador et al., 2011). Individuals willing to make this investment in their organizations should be rewarded with an even deeper sense of purpose and affinity, and the sense that they are accomplishing their work-related goals (Pratt \& Ashforth, 2003).

To summarize, in some instances, callings should be associated with personal and work relationships that are positive and enriching for the individual. In comparing healthy to unhealthy pursuit of one's callings, it may be helpful to think of unhealthy pursuit of callings as representing the beneficial aspects of callings taken to the extreme, to the point where the passion can become detrimental. For example, while those for whom pursuing a calling is healthy may exhibit a healthy commitment to, and investment in work, those for whom pursuing a calling becomes unhealthy may be better characterized by an overcommitment or overinvestment to the work domain (Harpaz \& Snir, 2003). Like workaholics, those engaged in unhealthy pursuit of a calling may exhibit work habits and attitudes that become so exaggerated that they constitute a danger to their relationships, and thus to their health, personal happiness, and social functioning (Evans \& Bartoleme, 1981).

Thus far, we have outlined the differences between healthy and unhealthy pursuit of one's calling, focusing specifically on individual well-being in terms of personal and work relationships. Our arguments suggest the presence of a third factor that may influence why pursuing a calling may be healthy versus healthy for one's relationships, and thus one's personal well-being. In the next section, we highlight work identity as a potentially important factor shaping a healthy versus unhealthy pursuit of one's calling with respect to one's relationships.

\section{The Role of Work-Identity Flexibility}


Work identity captures one's self-definition with respect to one's work role (Pratt et al., 2006). While work identity may be comprised of multiple social-based and/or role-based identities (Ashforth et al., 2008), here, we define work identity broadly as the various meanings that a person attaches to himself or herself at work (cf. Caza \& Wilson, 2009; Dutton, Roberts, \& Bednar, 2010). Scholars have noted that individuals can differ in the degree of flexibility they attach to their work identity; flexibility is characterized by the degree to which people are willing to engage in deliberate and informed comparison of one's present work-identity commitments with other possibilities, and/or by the degree of readiness to initiate change or to demonstrate plasticity in response to life events and circumstances (Grotevant, Thorbecke, \& Meyer, 1982). Put simply, work-identity flexibility helps individuals to adapt their present work identity in response to challenges, stressors, and work and life circumstances.

At a general level, identity flexibility has been linked to the capability to respond effectively to different circumstances and roles (Linville, 1987). Identity flexibility aids in psychological adjustment to change or negative life events because the greater the flexibility, the smaller the proportion of the self that is affected when such a change or negative event occurs (Linville, 1987). This flexibility allows individuals to adapt to or bounce back from setbacks and challenges, and even to engage the environment more proactively (Caza \& Wilson, 2009). In the work domain, work-identity flexibility involves a high degree of adaptability and self-awareness. As noted by Briscoe and Hall (1999), this type of flexibility allows workers to gather accurate self-related feedback, form accurate self-perceptions, and adjust one's self-concept as appropriate. According to Hall and Chandler (2005), “... a person with high adaptability would have the capacity to engage proactively in the process of goal setting, initiating effort, and achieving psychological success..." (pp. 163-164). Work-identity flexibility should be highly significant in the context of one's calling because, as noted, those with a calling tend show high levels of identity investment in work.

There is substantial evidence that successful individuals form, transform, and adjust how they define themselves and others in the context of work (Ibarra, 2003; Pratt et al., 2006). While researchers have uncovered various pathways through which work identities are constructed, less is known about how the flexibility of one's work identity might shape one's experience of work generally, and one's experience of work as a calling specifically. Our theory specifies that workidentity flexibility will influence how individuals will respond relationally to the reality of the stressors and challenges they encounter while pursuing their calling. Specifically, we posit that work-identity flexibility will facilitate positive and enriching relationships - and thus a healthy pursuit of one's calling, while work-identity rigidity should contribute to negative and depleting relationships — and thus an unhealthy pursuit of one's calling.

Work-identity flexibility and healthy pursuit of a calling

As noted above, workers with identity flexibility are able to gather self-related feedback to form accurate self-perceptions and to change their self-concept as appropriate (Briscoe \& Hall, 1999). This flexibility allows individuals to account for the needs of others and use adaptive strategies to respond to workplace challenges and adversity (Kock, 1985). Organizational scholars have begun to uncover the benefits of flexible work identities, or work identities that change or shift with the demands of one's career. For example, Pratt, Rockmann, and Kaufmann (2006) 
demonstrate that medical residents who made "identity changes" reported a greater degree of mastery and competence in their role than those that did not. Further, research by Parker, Williams, and Turner (2006) shows that individuals who have flexible orientations, or who define their role broadly, are more likely to demonstrate proactive problem solving and idea implementation. When individuals have this type of identity flexibility, they can account for the needs and interests of others in the work context and can more effectively use adaptive strategies to respond to work place challenges and adversity. Those with work-identity flexibility are more open to allowing others to penetrate and shape their work identities and can thus more easily build and forge positive relationships with others and their organization (Dutton et al., 2010). The following quote taken from a study of nurses with callings illustrates this type of workidentity flexibility:

People that have a calling just are willing to take what the assignment brings. You know, you're willing to adjust. You're willing to go the ways it needs to be. And you don't get all uptight over that stuff. \{Those that can't adjust] are the people that, you know, who get the ulcers, the people that are all up in a wad about stuff every day. You don't need to be ... I see it as more of a difficult challenge and when the difficulty starts going up the ladder, then you know, then I'm a resource person. I start going after my resources and pulling other people in before I get to that frustration point. (Nurse, 21)

Work-identity flexibility should enhance the ability of those with callings to function effectively in the organization and to access greater relational and personal resources. Accordingly, workidentity flexibility should be associated with a healthy pursuit of one's calling because it helps workers with callings to preserve and even strengthen their organizational and work relationships and fosters more effective integration of one's work and personal lives. This suggests that those engaged in a healthy pursuit of their calling may exhibit behaviors akin to adaptive workaholism (Mitchelson, 2009), whereby individuals have high personal standards and devote effort to high performance but maintain flexibility in role relations and openness to discrepancies between their standards and what the situation affords. Individuals with this type of approach are able to account for the needs of others and use adaptive strategies to respond to workplace challenges and adversity (Kock, 1985). This buffers workers from the negative effects of regular work stressors and thus protects against negative outcomes, such as emotional exhaustion and burnout (Mitchelson \& Burns, 1998). In turn, a well-balanced system of workplace relationships leads to higher subjective well-being (Marks \& MacDermid, 1996). This should be associated with a more heightened sense of contribution and greater work fulfillment over time (Pratt \& Ashforth, 2003; Wrzesniewski et al., 2003).

Work-identity rigidity and unhealthy pursuit of a calling

In contrast to work-identity flexibility, work-identity rigidity stems from the desire to want to uphold a rigid idea of who one is at work. This tendency becomes even more prominent when individuals encounter stressors that challenge their identity or confront conditions under which identity adaptation is required (Block, 1961). A rigid work identity should be associated with an unyielding portrait of who one is while fulfilling one's calling. This can manifest itself in rigid expectations about how things should be done and what the ideal outcomes should be. When under stress individuals may cling to these ideal notions, thereby limiting their ability for 
adaptation and straining relationships with those who have a dissimilar view of work. People with rigid work identities have a single way of viewing who they are and what they do at work and are unwilling or unable to bend this image to fit with the reality of their work situation (Briscoe \& Hall, 1999). In so doing, they are less able to account for the needs and interests of others in the workplace.

Those with this type of rigidity may have difficulty adjusting to situational demands, actions imposed by others, or even receiving feedback from others (Kock, 1985). In turn, they may find it difficult to respond to the relational stressors, challenges or changes in routine that are common to professions. Furthermore, they may be unwilling to compromise their heightened expectations and be less accepting of management action that threatens their professional ideal (Bunderson \& Thompson, 2009). This risk is surfaced by research showing that employees with strong and rigid ideals can quickly become disillusioned with organizations and those in them who they perceive to be failing these ideals (Foreman \& Whetten, 2002). As a result, when callings are coupled with rigid work identities, individuals should be more are likely to have difficulty maintaining flexibility in their personal and work relationships. Thus, they will be less able to sustain themselves personally or professionally for an extended period of time. The following quotes from a study of nurses with callings illustrate the difficulty they have with others in their organization who they perceive as failing to live up to their ideal:

When I am so passionate about something, and I see something that is not fair, I open my mouth. And then, I'm like, "They don't want to hear you." 'Cause sometimes they're not gonna listen to what you say, or sometimes I feel like I'm the nagger that says, "Oh, here she comes again with another problem." But, you know, it's just because I care so much ... \{I got into $\}$ nursing to make a difference, to help people, to make a difference in people's lives and I think that the politics, the not being able to influence anything around them is very frustrating. 'Cause when I don't like my job, that's what I don't like. It's systems or people or whoever that are doing something for whatever reason. (Nurse, 23)

When I got here I was like, “Whatever! You won't even change people's sheets every day. Why should I do things your way? Because obviously you don't know what you're doing ... I get so irritated. (Nurse, 04)

In short, those with greater work-identity rigidity should show a reduced ability to accommodate to the natural relational challenges and stressors in their work. In turn, the decreased quality of one's relational fabric will lead to a diminished ability to function effectively in the organization and to difficulty maintaining a healthy integration of one's work and personal lives. These factors will result in reduced personal well-being.

\section{Discussion}

We believe that our framework has several theoretical implications for the study of callings. First, the majority of research on callings has focused mainly on positive outcomes associated with one's calling. While there has been some recent work suggesting the possible downsides of callings, there is little work that combines the two perspectives in search of variables that may determine when a calling might be good and when it may be bad. The framework presented here 
is an early step toward understanding the complexity of positive and negative effects of callings by showing when and why pursuit of callings may sometimes be unhealthy or detrimental to the well-being of the individuals who hold them.

Second, in highlighting the relation between pursuit of a calling and personal, work and organizational relationships, this article takes an initial step toward developing an explicit relational theory of callings. As noted, the idea that the experience of one's work as a calling is often a social experience is not new (Wrzesniewski, 2010). Nevertheless, the extant literature has not yet addressed the direct impact of the pursuit of one's calling on the quality of one's relationships. While scholars have linked callings to factors such as job satisfaction (Wrzesniewski et al., 1997), occupational identification (Bunderson \& Thompson, 2009) and organizational commitment and identification (Cardador et al., 2011; Duffy et al., 2011), this is the first work to our knowledge to link one's pursuit of a calling to the relationships that one forms in and around work. In so doing, this work offers an important contribution by shedding light on how callings might affect one's interpersonal relationships — both positively and negatively.

Third, this framework contributes to an understanding of how work identity may shape people's experience of calling. While most research on callings focuses on the strength of one's work identity, noting that strong and well-developed work identities are associated with greater engagement and fulfillment in work (Pratt \& Ashforth, 2003; Dobrow, 2004), this framework suggests that the flexibility of one's work identity may also be important. Our theory suggests that it may not only be the strength and clarity of the work identity that is important for one's sense of calling, but also how one's work identity is enacted (i.e., in a flexible vs. rigid manner). In articulating this possibility, this framework helps to move the conversation about callings and identity toward an understanding of the specific ways in which work identity and one's experience of calling are linked. Moreover, linking healthy pursuit of callings to work-identity flexibility contributes to the growing literature on how the structure of one's identity contributes to important personal and work-related outcomes.

Finally, while our theory does not specifically highlight the ways in which callings unfold over time, it may have implications for the specific trajectories that a calling may take. The most traditional view of calling is one in which individuals thrive in their work and nonwork relationships. This can be considered a progressive trajectory, characterized by growth in the strength of one's calling over time. According to Gergen (1994), progressive trajectories involve growth and advancement toward a desired goal or outcome, whereby experience exceeds personal expectations. The healthy pursuit of one's calling should be likely to follow a progressive trajectory. Under this scenario, investment in the work role leads people toward behaviors which promote supportive relationships with others and the organization. When faced with difficult work events and challenges, workers engaged in healthy pursuit of callings should be more likely to reframe them as opportunities for growth, learning, and development (Thompson, 1985). They should be more able to see benefits in their personal and work relationships, and may therefore be better able to overcome events or situations that challenge their calling. The work-identity flexibility associated with the healthy pursuit of a calling should allow the individual to progress toward a higher-order stage of development, thereby contributing to growth in the strength and significance of one's calling over time. 
In contrast, this research has also suggested one of the pathways through which callings might take a regressive trajectory associated with a diminished strength and significance of one's calling. Regressive trajectories refer to those that involve moving further away from one's desired goal or outcome, such that individuals are unable to align their personal experience with their work goals (Gergen, 1994). Regressive calling trajectories should be more likely to result from negative and depleting relationships associated with a rigid work identity with respect to one's calling. In this trajectory, investing in one's calling leads people toward behaviors which undermine positive interpersonal relationships and relationships with one's organization. As a result, workers are likely to shift their perceptions of whether they are making progress toward achieving their purpose in work. They are no longer able to align their daily experience of work with the meaning and purpose they desire. This is likely to involve increased stress, and a shift in one's interpretation of the meaning of work (Carver \& Scheier, 1991; Park \& Folkman, 1997). Those engaged in unhealthy pursuit of callings should possess the desire to find work meaningful but experience relational roadblocks to doing so. Under these conditions, one's calling should diminish in strength and significance over time. Linking the healthy pursuit of callings to progressive trajectories and the unhealthy pursuit of callings to regressive trajectories might help provide an explanation of why some individuals are able to sustain or grow in their calling, while others lose their sense of calling. While others have suggested that callings often involve sacrifice (Bunderson \& Thompson, 2009), this framework provides some indication of the point at which sacrifice - in the form of strained relationships with others and one's organizationmay interfere with one's ability to sustain a calling. This framework may also help explain individual level variance in rates of burnout in contexts where some people languish while others thrive.

The ideas presented here have important practical implications as well. In many cases, clients seek work that will bring maximal satisfaction, often in the form of increased meaning and purpose (Dik, Duffy, \& Eldridge, 2009). Our research suggests that career counselors should not only assist clients in finding their calling but also in learning how to follow their calling. Often it is assumed that acquiring a sense of calling might be the end result of successful career counseling and planning (Finney \& Dasch, 1998); however, we suggest that it is just as critical to consider how the call is enacted. We propose that a sustainable sense of calling needs to be flexibly enacted if individuals and their employing organizations are to reap the rewards, and avoid the costs, of this highly valued view of work. We posit that when individuals have strong work identities - such as those associated with callings - but are not flexible in their approach to work, it may lead to forms of entrenchment and an inability to respond appropriately when workers encounter stressors or challenges in their work. Accordingly, it is important for career counselors to teach workers with a strong sense of calling to be adaptive and flexible in their work identity (Caza \& Wilson, 2009). Encouraging workers to have both strong and flexible work identities may be a tall order, given that in some cases, strong work identities may contribute to greater inflexibility. For instance, in Weick's (1993) analysis of the Mann Gulch disaster, firefighters were so strongly entrenched in their identities that they were unable to "drop their tools" when the situation called for it and lost their lives as a result. However, it would seem that if workers are more capable and willing to adjust to their view their work, they may be able to better respond to the natural stressors and challenges associated with high personal investment in work. This becomes even more important if individuals are pursuing their calling. 
As we have pointed out, pursuing one's calling has the potential to be associated with either strengthening of relational bonds or the alienation of others. The ability to adjust one's view of work is a key factor in determining which of these scenarios individuals experience. To assist clients with inflexible work identities, career counselors may want to work with these individuals to aid them in developing behaviors associated with positive work and nonwork relationships, such as adaptability, cooperation, balance, and openness. In doing so, they may help clients to buffer the negative effects of a rigid work identity. However, it is important to remember that even for individuals with the most flexible of work identities, challenges, and stressors created by a hostile or unsupportive work environment may weaken a sense of calling. Given evidence that those with callings tend to form strong attachment to their employing organizations (Cardador et al., 2011; Duffy et al., 2011), they may remain in depleting work environments or be susceptible to organizational exploitation (Bunderson \& Thompson, 2009). Therefore, career counselors may need to actively guide clients away from such work environments in order to help them retain their sense of calling.

\section{Conclusion}

A calling orientation can lead to increased subjective well-being, but pursuit of one's calling may also be a difficult path that leads to high sacrifice, personal strain, and depletion, resulting in lowered subjective well-being. We suggest that individuals are engaged in healthy pursuit of their callings when they are able to develop and sustain positive and mutually rewarding personal and work relationships, facilitated by not only a strong investment in work but also a flexible work identity. This flexibility allows individuals to adapt to natural changes in their profession, their own lives, and their organizational environment. In contrast, individuals are engaged in unhealthy pursuit of callings when they form negative and depleting relationships, facilitated by a strong investment in work accompanied by a rigid work identity. Without work-identity flexibility, individuals with callings have more difficulty adapting to the natural changes and stressors in their profession, lives, and work environment.

Declaration of Conflicting Interests. The authors declared no potential conflicts of interest with respect to the research, authorship, and/or publication of this article.

Funding. The authors received no financial support for the research, authorship, and/or publication of this article.

\section{References}

Ashforth, B. E. (2001). Role transitions in organizational life: An identity-based perspective. Mahwah, NJ: Lawrence Erlbaum.

Bakker, A. B., Demerouti, E., Burke, R. (2009). Workaholism and relationship quality: A spillover-crossover perspective. Journal of Occupational Health Psychology, 14, 23-33. doi:10.1037/a0013290 
Baumeister, R. F., Leary, M. R. (1995). The need to belong: Desire for interpersonal attachments as fundamental human motivation. Psychological Bulletin, 117, 497-530. doi:10.1037/ 0033-2909.117.3.497

Bellah, R. N., Madsen, R., Sullivan, W. M., Swidler, A., Tipton, S. M. (1985). Habits of the heart: Individualism and commitment in American life. New York, NY: Harper and Row.

Block, J . (1961). Ego identity, role variability, and adjustment. Journal of Consulting Psychology, 25, 392-397. doi:10.1037/h0042979

Briscoe, J. P., Hall, D. T. (1999). An alternative approach and new guidelines for practice. Organizational Dynamics, 28, 37-51. doi:10.1016/S0090-2616(00)80015-7

Bunderson, J. S., Thompson, J. A. (2009). The call of the wild: Zookeepers, callings, and the double-edged sword of deeply meaningful work. Administrative Science Quarterly, 54, 32-57. doi:0001-8392/09/5401-0032

Cardador, M. T., Dane, E. I., Pratt, M. G. (2011). Linking calling orientations to organizational attachment via organizational instrumentality. Journal of Vocational Behavior, 79, 367378. doi:10.1016/j.jvb.2011.03.009

Carlson, D., Witt, L., Zivnuska, S., Kacmar, K., Grzywacz, J. (2008). Supervisor appraisal as the link between family-work balance and contextual performance. Journal of Business \& Psychology, 23, 37-49. doi:10.1007/s10869-008-9083-z

Carver, C. S., Scheier, M. F. (1991). Self-regulation and the self. In Straus, J., Goethals, G. R. (Eds.), The self: Interdisciplinary approaches (pp. 168-207). New York, NY: Springer.

Caza, B., Wilson, M. K. (2009). Me, myself, and I: The benefits of multiple work identities. In Roberts, L. M., Dutton, J. E. (Eds.), Positive identities and organizations. New York, NY: Psychology Press.

Colby, A., Sippola, L., Phelps, E. (2001). Social responsibility and paid work in contemporary American life. In Rossi, A. (Ed.), Caring and doing for others: Social responsibility in the domains of family, work, and community (pp. 349-399). Chicago, IL: University of Chicago Press.

De Dreu, C. K. W., Van Dierendonck, D., De Best-Waldhober, M. (2002). Conflict at work and individual wellbeing. In Schabracq, M., Winnubst, J. A. M., Cooper, C. L. (Eds.), The handbook of work and health psychology (pp. 369-414). Chichester, England: Wiley.

Diener, E . (2000). Subjective well-being: Science of happiness and a proposal for a national index. American Psychologist, 55, 34-43. doi:10.1037//0003-066X.55.1.34

Dik, B. J., Duffy, R. D. (2009). Calling and vocation at work: Definitions and prospects for research and practice. The Counseling Psychologist, 37, 424-450. doi:10.1177/ 0011000008316430

Dik, B. J., Duffy, R. D., Eldridge, B. M. (2009). Calling and vocation in career counseling: Recommendations for promoting meaningful work. Professional Psychology: Research and Practice, 40, 625-632. doi:10.1037/a0015547 
Dobrow, S. R. (2004). Extreme subject career success: A new integrated view of having a calling. Academy of Management Proceedings, B1-B6.

doi:10.5465/AMBPP.2004.13863838

Dobrow, S. R . (2006). Having a calling: A longitudinal study of young musicians (Unpublished doctoral dissertation). Cambridge, MA: Harvard University.

Duffy, R. D., Dik, B. J., Steger, M. F. (2011). Calling and work-related outcomes: Career commitment as a mediator. Journal of Vocational Behavior, 78, 210-218. doi:10.1016/j.jvb.2010.09.013

Duffy, R., Sedlacek, W. (2007). The presence and search for a calling: Connections to career development. Journal of Vocational Behavior, 70, 590-601. doi:10.1016/ j.jvb.2007.03.007

Dutton, J. E., Heaphy, E. D. (2003). The power of high quality connections, In Cameron, K. S., Dutton, J. E., Quinn, R. E. (Eds.), Positive organizational scholarship: Foundations of a new discipline (pp. 263-278). San Francisco, CA: Berrett-Koehler.

Dutton, J. E., Roberts, L. M., Bednar, J. (2010). Pathways for positive identity construction at work: Four types of positive identity and the building of social resources. Academy of Management Review, 35, 265-293.

Eckenrode, J., Gore, S. (1990). Stress and coping at the boundary of work and family. In Eckenrode, J., Gore, S. (Eds.), Stress between work and family (pp. 1-16). New York, NY: Plenum.

Elangovan, A. R., Pinder, C. C., McLean, M. (2010). Callings and organizational behavior. Journal of Vocational Behavior, 76, 428-440. doi:10.1016/j.jvb.2009.10.009

Evans, P., Bartoleme, F. (1981). Must success cost so much? New York, NY: Basic Books.

Finney, M., Dasch, D. (1998). Find your calling, Love your life. New York, NY: Simon \& Schuster.

Foreman, P., Whetten, D. A. (2002). Members' identification with multiple identity organizations. Organization Science, 13, 618-635. doi:10.1287/orsc.13.6.618.493

Ganster, D. C., Schaubroeck, J. (1991). Work stress and employee health. Journal of Management, 17, 235-271. doi:10.1177/014920639101700202

Gergen, K. J. (1994). Realities and relationships: Soundings in social construction. Boston, MA: Harvard University Press.

Gersick, C. J., Dutton, J. E., Bartunek, J. M. (2000). Learning from academia: The importance of relationships in professional life. Academy of Management Journal, 43, 1026-1044. doi: $10.2307 / 1556333$

Gini, A. (1998). Work, identity and self: How we are formed by the work we do. Journal of Business Ethics, 17, 707-714.

Greenhaus, J. H., Buetell, N. J. (1985). Sources of conflict between work and family roles. Academy of Management Review, 10, 76-88. 
Grotevant, H. D., Thorbecke, W., Meyer, M. L. (1982). An extension of Marcia's identity status interview into interpersonal domain. Journal of Youth and Adolescence, 11, 33-47.

Hall, D. T., Chandler, D. E. (2005). Psychological success: When the career is a calling, Journal of Organizational Behavior, 26, 155-176. doi:10.1002/job.301

Harpaz, I., Snir, R. (2003). Workaholism: Its definition and nature. Human Relations, 56, 291319. doi:10.1177/0018726703056003613

Hartnett, S., Kline, F. (2005). Preventing the fall from the call to teach. The Journal of Christian Faith and Belief, 9, 9-20.

Hirschi, A . (2011). Callings in career: A typological approach to essential and optional components. Journal of Vocational Behavior, 79, 60-73. doi:10.1016/j.jvb.2010.11.002

Hunter, I., Dik, B. J., Banning, J. H. (2010). College students' perceptions of calling in work and life: A qualitative analysis. Journal of Vocational Behavior, 76, 178-186. doi:10.1016/ j.jvb.2009.10.008

Ibarra, H. (2003). Working identity: Unconventional strategies for reinventing your career. Cambridge, MA: Harvard University Press.

Isen, A. M., Baron, R. A. (1991). Positive affect as a factor in organizational behavior. Research in Organizational Behavior, 13, 1-53.

Johnstone, A., Johnson, L. (2005). The relationship between organizational climate, occupational type and workaholism. New Zealand Journal of Psychology, 34, 181-188.

Judge, T. A., Bretz, R. D., . (1992). Effects of work values on job choice decisions. Journal of Applied Psychology, 77, 261-271. doi:10.1037/0021-9010.77.3.261

Kahn, W. A. (1998). Relational systems at work. In Staw, B. M., Cummings, L. L. (Eds.), Research in organizational behavior (pp. 39-76). Greenwich, CT: JAI Press.

Kahn, W. A. (2007). Meaningful connections: Positive relationships and attachments at work. In Dutton, J. E., Ragins, B. R. (Eds.), Exploring positive relationships at work (pp. 189206). Mahwah, NH: Lawrence Erlbaum.

Kennedy, F. A., Loughry, M. L., Klammer, T. P., Beyerlein, M. M. (2009). Effects of organizational support on potency in work teams. Small Group Research, 40, 72-93. doi:10.1177/1046496408326744

Kock, A. (1985). A strategy for prevention: Role flexibility and affective reactivity as factors in family coping. Family Systems Medicine, 3, 70-81.

Levoy, G. (1997). Callings: Finding and following an authentic life. New York, NY: Crown.

Linville, P. W . (1987). Self-complexity as a cognitive buffer against stress-related illness and depression. Journal of Personality and Social Psychology, 52, 663-676. doi:10.1037/0022-3514.52.4.663

Marks, S. R., MacDermid, S. M. (1996). Multiple roles and the self: A theory of role balance. Journal of Marriage and the Family, 58, 417-432. 
Mitchelson, J. K . (2009). Seeking the perfect balance: Perfectionism and work-family conflict. Journal of Occupational \& Organizational Psychology, 82, 349-367. doi:10.1348/ $096317908 \times 314874$

Mitchelson, J. K., Burns, L. R. (1998). career mothers and perfectionism: Stress at work and at home. Personality and Individual Differences, 25, 477-486. doi:10.1016/S01918869(98)00069-5

Ng, T. W. H., Sorensen, K. L., Feldman, D. C. (2007). Dimensions, antecedents, and consequences of workaholism: A conceptual integration and extension. Journal of Organizational Behavior, 28, 111-136. doi:10.1002/job.424

Novak, M. (1996). Business as a calling: Work and the examined life. New York, NY: Free Press.

Oates, K. L. M., Hall, M. E. L., Anderson, T. L. (2005). Calling and conflict: A qualitative exploration of interrole conflict and the sanctification of work in Christian mothers in academia. Journal of Psychology \& Theology, 33, 210-223.

Park, C. L., Folkman, S. (1997). Meaning in the context of stress and coping. General Review of Psychology, 1, 115-144. doi:10.1037/1089-2680.1.2.115

Parker, S. K., Williams, H., Turner, N. (2006). Modeling the antecedents of proactive behaviour at work. Journal of Applied Psychology, 91, 636-652. doi:10.1037/0021-9010.91.3.636

Pines, A. M., Aronson, E., Kafry, D. (1981). Burnout: From tedium to personal growth. New York, NY: Free Press.

Piotrowski, C., Vodanovich, S. J. (2006). The interface between workaholism and work family conflict: A review and conceptual framework. Organization Development Journal, 24, 84-92.

Porter, G . (1996). Organizational impact of workaholism: Suggestions for researching the negative outcomes of excessive work. Journal of Occupational Health Psychology, 1, 70 84. doi:10.1037/1076-8998.1.1.70

Pratt, M. G., Ashforth, B. E. (2003). Fostering meaningfulness in working and at work. In Cameron, K. S., Dutton, J. E., Quinn, R. E. (Eds.), Positive organizational scholarship: Foundations of a new discipline (pp. 309-327). San Francisco, CA: Berrett-Koehler.

Pratt, M. G., Dirks, K. T. (2007). Rebuilding trust and restoring positive relationships: A commitment-based view of trust. In Dutton, J. E., Ragins, B. R. (Eds.), Exploring positive relationships at work (pp. 117-136). Mahwah, NH: Lawrence Erlbaum.

Pratt, M. G., Rockmann, K. W., Kaufmann, J. B. (2006). Constructing professional identity: The role of work and identity learning cycles in the customization of identity among medical residents. Academy of Management Journal, 49, 235-262. doi:10.5465/ AMJ.2006.20786060

Ragins, B. R., Dutton, J. E. (2007). Positive relationships at work: An introduction and invitation. In Dutton, J. E., Ragins, B. R. (Eds.), Exploring positive relationships at work (pp. 3-25). Mahwah, NH: Lawrence Erlbaum. 
Reis, H. T., Gable, S. L. (2003). Toward a positive psychology of relationships. In Keyes, C. L., Haidt, J. (Eds.), Flourishing: The positive person and the good life (pp. 129-159). Washington, DC: American Psychological Association.

Roberts, L. M. (2007). From proving to becoming: How positive relationships create a context for self-discovery and self-actualization. In Dutton, J. E., Ragins, B. R. (Eds.), Exploring positive relationships at work (pp. 29-45). Mahwah, NH: Lawrence Erlbaum.

Rothbard, N. P. (2001). Enriching or depleting: The dynamics of engagement in work and family roles. Administrative Science Quarterly, 46, 655-684.

Ryan, R. M., Deci, E. L. (2000). Self-determination theory and the facilitation of intrinsic motivation, social development and well-being. American Psychologist, 55, 68-79. doi:10.1037110003-066X.55.1.68

Scott, K. S., Moore, K. S., Miceli, M. P. (1997). An exploration of the meaning and consequences of workaholism. Human Relations, 50, 287-314. doi:10.1177/001872679705000304

Sellers, T. S., Thomas, K., Batts, J., Ostman, C., (2005). When called: A qualitative study of Christian women dually called to motherhood and career. Journal of Psychology \& Theology, 33, 198-209.

Serow, R. C. (1994). Called to teach: A study of highly motivated preservice teachers. Journal of Research and Development in Education, 27, 65-72.

Seltzer, J., Numerof, R., Bass, B. (1989). Transformational leadership: Is it a source of more burnout and stress? Journal of Health \& Human Resources Administration, 12, 174-185.

Shamir, B. (1991). Meaning, self and motivation in organizations. Organization Studies, 12, 405-424. doi:10.1177/017084069101200304

Sherman, D. (2004). Nurses' stress and burnout: How to care for yourself when caring for patients and their families experiencing life-threatening illness. American Journal of Nursing, 104, 48-56.

Sirgy, M. J., Wu, J. (2009). The pleasant life, the engaged life and the meaningful life: What about the balanced life? Journal of Happiness Studies, 10, 183-196. doi:10.1007/s10902007-9074-1

Spence, J. T., Robbins, A. S. (1992). Workaholism: Definition, measurement, and preliminary results. Journal of Personality Assessment, 58, 160-178.

Thompson, S. C. (1985). Finding positive meaning in a stressful event and coping. Basic and Applied Social Psychology, 6, 279-295.

Vinje, H. F., Mittelmark, M. B. (2007). Job engagement's paradoxical role in nurse burnout. Nursing \& Health Sciences, 9, 107-111. doi:10.1111/j.1442-2018.2007.00310.x

Weick, K. (1993). The collapse of sensemaking in organizations: The Mann Gulch disaster. Administrative Science Quarterly, 38, 628-652. 
Wrzesniewski, A. (2003). Finding positive meaning in work. In Cameron, K. S., Dutton, J. E., Quinn, R. E. (Eds.), Positive organizational scholarship: Foundations of a new discipline (pp. 296-308). San Francisco, CA: Berrett-Koehler.

Wrzesniewski, A. (2010). Callings. In Cameron, K., Spreitzer, G. (Eds.), Handbook of positive organizational scholarship. New York, NY: Oxford University Press.

Wrzesniewski, A., Dekas, K., Rosso, B. (2009). Calling. In Lopez, S. J., Beauchamp, A. (Eds.), The encyclopedia of positive psychology (pp. 115-118). Malder, MA: Blackwell.

Wrzesniewski, A., Dutton, J. E., Debebe, G. (2003). Interpersonal sensemaking and the meaning of work. Research in Organizational Behavior, 25, 93-135. doi:10.1016/S01913085(03)25003-6

Wrzesniewski, A., McCauley, C., Rozin, P., Schwartz, B. (1997). Jobs, careers, and callings: People's relations to their work. Journal of Research in Personality, 31, 21-33. doi:10.1006/jrpe.1997.2162 